\title{
Identification of Neuregulin 1 as Predictor Outcome in Intracranial Astrocytoma
}

\author{
Ridha Dharmajaya*(D), Abdurrahman Mouza (iD \\ Department of Neurosurgery, Faculty of Medicine, Universitas Sumatera Utara, Medan, Indonesia
}

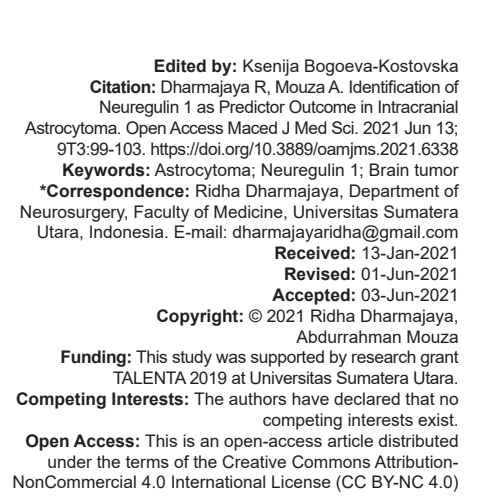

\section{Introduction}

Astrocytoma is the most common primary brain tumor. In the United States, incidence of astrocytoma is 6.5 per 100.000 population, whereas mortality rate are 12.760 cases. Annually, new cases of high-grade astrocytoma are 11.000 cases [1]. Astrocytoma is a tumor from glial cell, called astrocyte. The World Health Organization classifies astrocytoma using four grades according to the growth rate and metastasis [2]. Astrocytoma is usually found in male and adult patient [3].

Astrocytoma is one of brain tumors that can have metastases. The metastasis is facilitated by proliferation and migration of cell tumor. A complex interplay among adhesion molecules, proteases, and cytokines that regulate their expression likely underlies tumor progression and invasion [4]. Cytokine that affected the growth of cell tumor was known for long time. Among cytokines, NRG1 plays the most important role in growing and migration of cell tumor. Complex interplay between NRG1 and receptor activate intracell biology process adding to tumorigenesis [5].
Neuregulin 1 expression is considered as a prognostic parameter of an astrocytoma. In low-grade astrocytoma, age is one of significant risk factors in predicting outcome [6].

Complex interplay between NRG1 and ErbB receptor affects mouse brain glial cell changed to be malignant astrocytoma. This binding induces differentiation and proliferation of mouse astrocyte cell. Zhao in 2013 indicated that $\mathrm{L} 1$, a transmembrane adhesion molecule of the immunoglobulin superfamily, plays important roles in tumor progression and metastatic behavior [7].

The trigger of the growth and migration of tumor is suspected by overexpression of the NRG1 and ErbB signal. Inhibition of NRG1 signaling inhibited primary tumor growth and enhanced the magnitude and duration of the respond to chemotherapy [8].

The purpose of this study was to analyze the expression of NRG1 on human astrocytoma. The relationship of NRG1 and characteristic of patient of intracranial astrocytoma is observed. The role of NRG1 in astrocytoma prognosis in the Indonesian population is not clear. Therefore, the researcher 
is interested to study the relationship of NRG1 and characteristic of patient of intracranial astrocytoma patients.

\section{Methods}

\section{Inclusion criteria for patients}

Patients were diagnosed with intracranial astrocytoma by clinical and radiological parameters. Patients were operated by tumor removal. The definitive diagnose was confirmed by anatomy pathology study.

\section{Exclusion criteria for patients}

Patients have comorbid diseases such as diabetes mellitus, renal, and liver dysfunctions. Patients have recurrence and recidive of astrocytoma. There are other tumors, such as breast cancer, cardiac cancer, ovarian cancer, and prostate cancer. All patients and controls gave informed consent, and the study protocol was approved by the Institutional Ethics Committee.

\section{Study design}

The study analyzes relationship of NRG1 and the characteristic of patient of intracranial astrocytoma who were admitted in Adam Malik Hospital, Medan. This study is a retrospective study that is using an analytic method. The study included 32 samples. The sampling technique of this study is total sampling. The study was undertaken at Adam Malik Hospital, Medan since September 2016-August 2018.

\section{Technique of sample collection}

All paraffin specimen of astrocytoma and data of the patients from September 2016 to August 2018 were collected from medical record and data of neurosurgery department assessment.

The data included gender, age, the WHO histopathology grading of astrocytoma, cell proliferation, outcome, and NRG1 expression. The cell proliferation and NRG1 immunohistochemistry tests are performed in all paraffin specimens.

Cell proliferation interpretation is recorded as followed: mild group as < 4 mitotes per 10 High Power Field (HPF), moderate group as 4-19 mitoses per $10 \mathrm{HPF}$, and high group as $>20$ mitoses per $10 \mathrm{HPF}^{9}$, (Figure 1). Interpretation of intensity $(0,1+, 2+$, and $3+)$ and percentage of immunoreactive cells of neuregulin 1

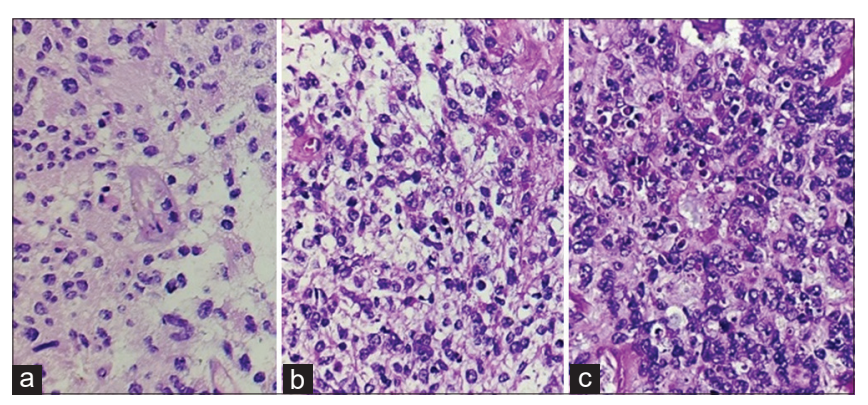

Figure 1: Cell proliferation. (a) Cell Proliferation: mild, (b) Cell Proliferation: moderate, (c) Cell Proliferation: high

staining were recorded as followed: $3+$, strong staining intensity in $50 \%$ cells; $2+$, moderate staining intensity in $50 \%$ cells; $1+$, faint or weak staining intensity in $50 \%$ cells; and 0 , no or equivocal staining in tumor cells or $50 \%$ of cells staining at any given intensity, which were defined as NRG1-negatif [9], (Figure 2).

Four micron-thick section of tumor slide is placed in positive charged slides Optiplus and heated at $60^{\circ} \mathrm{C}$ for $30 \mathrm{~min}$. Deparaffinization slide uses xylene as 2 times for $5 \mathrm{~min}$ and rehydrated by ethanol. Endogenus peroxidase activity is blocked with incubation at $100 \mu \mathrm{H}_{2} \mathrm{O}_{3} 3 \%$ and methanol at humid room for $5 \mathrm{~min}$. The slide is rehydrated by phosphate buffered saline (PBS). Antigen is got by giving buffer citrate ( $\mathrm{pH} \mathrm{6.0)}$ then cooled by RT for 20-30 min. The slide is blocked with goat serum 1:20 (BioGenex San Ramon, CA) for 20 min. The slide is incubated with monoclonal antibody NRG1 overnight in $4^{\circ} \mathrm{C}$, then it is washed with PBS and incubated $100 \mu$ streptavidinhorseradish peroxidase conjugate (Dako Corporation, EA 93013, USA) for $30 \mathrm{~min}$. The antibody is dripped by substrate 3,3'-diaminobenzidine for $10 \mathrm{~min}$. The slide is colored by hematocyline Mayer's for $30 \mathrm{~min}$, washed and rehydrated with ethanol, cleared with xylene, mount with mounting medium.

\section{Statistical analysis}

Statistical analysis was performed using Statistica software, ver 7.1. Due to the distribution which was not normal (according to KolmogorovSmirnov test), the variable differences were tested using non-parametric tests (Wilcoxon Matched Pair Test or Friedman ANOVA test - Chi-square). The correlation between parameters was analyzed using the Pearson correlation coefficient. Significance was set up at $p<0.05$.

\section{Results}

Data are preceded by software. Categoric variable is presented in frequency and percentage. Demography and medic data that include 


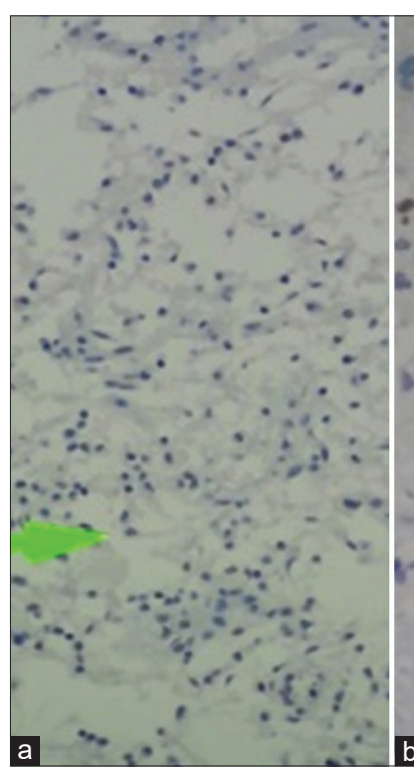

Figure 2: NRG1 expression. (d) Expression NRG1: Strong

name, age, the WHO histopathology grading of astrocytoma, cell proliferation, outcome, and NRG1 expression are analyzed by computerize using Spearman test. $p \leq 0.05$ means that there is significant relationship, otherwise $p$ value $>0.05$ means that there is not significant relationship NRG1 expression and age.

The study demonstrated that the most NRG1 expression is weak expression in adult as many $8(25 \%)$ samples, while the least NRG1 expression is negative expression and weak expression in children as many $2(6.3 \%)$ samples, respectively. After analyzing with Spearman test, there is not significant relationship between NRG1 expression and age $(p=0.853)$, Table 1 .

Table 1: NRG1 expression and age

\begin{tabular}{lllll}
\hline Category & Children $\mathrm{n}(\%)$ & Adult $\mathrm{n}(\%)$ & Elderly $\mathrm{n}(\%)$ & $\mathrm{p}$ \\
\hline None & $2(6.3)$ & $3(9.4)$ & $0(0)$ & 0.853 \\
Weak & $2(6.3)$ & $8(25)$ & $0(0)$ & \\
Moderate & $3(9.4)$ & $5(15.6)$ & $0(0)$ & \\
Strong & $3(9.4)$ & $6(18.8)$ & $0(0)$ & \\
\hline
\end{tabular}

\section{NRG1 expression and genre}

Weak NRG1 expression in male and strong NRG1 expression in male is the most finding NRG1 expression in this study, as many $6(18.8 \%)$ samples, respectively; otherwise, negative NRG1 expression in male is the least finding NRG1 expression in this study, as many $2(6.3 \%)$ samples. After analyzing with Spearman test, there is not significant relationship between NRG1 expression and genre ( $p=0.565)$, (Table 2).

Table 2: NRG1 expression and genre

\begin{tabular}{lll}
\hline Category & Male $\mathrm{n}(\%)$ & Female $\mathrm{n}(\%)$ \\
\hline None & $2(6.3)$ & $3(9.4)$ \\
Weak & $6(18.8)$ & $4(12.5)$ \\
Moderate & $3(9.4)$ & $5(15.6)$ \\
Strong & $6(18.8)$ & $3(9.4)$ \\
\hline
\end{tabular}

\section{NRG1 expression and cell proliferation}

The strong NRG1 expression with high cell proliferation is the most finding NRG1 expression, as many $10(31.1 \%)$ samples, while the moderate NRG1 expression with high cell proliferation is the least finding NRG1 expression. After analyzing with Spearman test, there is significant relationship between NRG1 expression and cell proliferation $(r=0.906, p=0.00)$, (Table 3).

Table 3: NRG1 expression and cell proliferation

\begin{tabular}{lllll}
\hline Category & Mild n (\%) & Moderate n (\%) & High n (\%) & $\mathrm{r}(\mathrm{p})$ \\
\hline None & $5(15.6)$ & 0 & 0 & 0.906 \\
Weak & $2(6.3)$ & $8(25)$ & 0 & \\
Moderate & 0 & $7(21.9)$ & $1(3.1)$ & $(0.00)$ \\
Strong & 0 & 0 & $10(31.1)$ & \\
\hline
\end{tabular}

\section{NRG1 expression and the WHO histopathology grading of astrocytoma}

The strong NRG1 expression in fourth grade of astrocytoma is the most finding, as many 7 (21.9\%) samples. Otherwise, the negative NRG1 expression in second grade of astrocytoma is the least finding, as many $1(3.1 \%)$ sample. After analyzing with Spearman test, there is significant relationship between NRG1 expression and the $\mathrm{WHO}$ histopathology grading of astrocytoma $(r=0.88, p=0.00)$, (Table 4).

Table 4: NRG1 expression and the WHO histopathology grading of astrocytoma

\begin{tabular}{llllll}
\hline Category & Grade I n (\%) & Grade II n (\%) & Grade III n (\%) & Grade IV n (\%) & $\mathrm{r}(\mathrm{p})$ \\
\hline None & $4(12.5)$ & $1(3.1)$ & 0 & 0 & $0.88(0.00)$ \\
Weak & $6(18.8)$ & $4(12.5)$ & 0 & 0 & \\
Moderate & 0 & $5(15.6)$ & $3(9.4)$ & 0 & \\
Strong & 0 & 0 & $5(15.6)$ & $7(21.9)$ & \\
\hline
\end{tabular}

\section{NRG1 expression and outcome}

Moderate NRG1 expression in live patient post tumor removal is the most findings, as many 
7 (21.9) samples; otherwise, moderate NRG1 expression in death patient post-tumor removal is the least finding, as many $1(3,1 \%)$ sample. After analyzing with Spearman test, there is significant relationship between NRG1 expression and outcome $(r=0.514$, $p=0.03$ ), (Table 5).

Table 5: NRG1 expression and outcome

\begin{tabular}{lll}
\hline Category of outcomes & Alive $\mathrm{n}(\%)$ & Death $\mathrm{n}(\%)$ \\
\hline None & $5(15.6)$ & 0 \\
Weak & $6(18.8)$ & $4(12.5)$ \\
Moderate & $7(21.9)$ & $1(3.1)$ \\
Strong & $3(9.4)$ & $6(18.8)$ \\
\hline
\end{tabular}

\section{Discussion}

Our study demonstrated that there is no significant relationship between NRG1 expression and age of patient $(p=0.853)$. It is not in accordance with Douet statement that subcortical (axon in white matter) changes typically emerged at adolescence. It suggests that peripubertal factors such as hormones affect this change [10]. The factor of this contradiction is suggested by limited numbers of samples.

The study showed that there is no significant relationship between NRG1 expression and age of patient $(p=0.853)$. It is accordance with Prevot statement that dysfunction of NRG1 in mice brain neither delay the sexuality growth nor infertile [11]. Taylor said that disfunction of NRG1 does not affect woman reproductive function [12]. In woman, neuregulin 1 does not have significant relationship with sexuality growth and function [13].

In this study, it was shown that there is significant relationship between NRG1 expression and $\mathrm{WHO}$ histopathology grading of astrocytoma $(r=0.88, p=0.00)$. This result is appropriate to Zhao statement which he indicated that $L 1$, a transmembrane adhesion molecule of the immunoglobulin superfamily, plays important roles in tumor progression and metastatic behavior [4].

Neuregulin 1 and ErbB receptor signal activity increases motility and migration of astrocytoma cell [13]. Neuregulin 1 affects astrocytoma cell migration. Neuregulin 1 expression of astrocytoma corresponds to astrocytoma grading [4].

It was shown that there is a significant relationship between NRG1 expression and cell proliferation $(r=0.906, p=0.00)$. The result is in accordance with Wadugu statement that NRG1 have some important function, such as differentiation of neuron cell, accumulation of acetylcholine receptors in skeletal muscle, and glial cell proliferation [14]. Neuregulin 1 and its receptor are found in growing and developing brain in neurogenesis and proliferation. Therefore, NRG1 has an important role in the regulation of central nervous system cell formation [15].
This study demonstrated that there is significant relationship between NRG1 expression and outcome $(r=0.514,0=0.03)$. This result is compatible to Anvari statement that the WHO grading of astrocytoma has relationship with mortality [16]. Ten survival rates of astrocytoma patients in Grade II astrocytoma are 35\%. The central nervous system cancer is the main cause of death of solid tumor in children and the third cause of death in adolescent and adult, especially at age 15-34 years old [1].

\section{Limitations of study}

The sample size was too small to allow for a generalization of the results.

\section{Conclusions}

There was significant association between NRG1 expression and cell proliferation, the WHO grading of astrocytoma and outcomes.

\section{Authors' Contributions}

Conception of the work: RD, AM; Design of the work: RD, AM; Acquisition/analysis/interpretation of the data: RD and AM. RD and AM have read and approved the final version of manuscript.

\section{Acknowledgments}

The authors would like to thank Universitas Sumatera Utara and the Department of Pathology Anatomy at Universitas Sumatera Utara, Indonesia.

\section{Ethics Approval and Consent to Participate}

Ethical approval by HEALTH RESEARCH ETHICAL COMMITTEE medical faculty of Universitas Sumatera Utara / Haji Adam Malik General Hospital. Consent to participate is not applicable for retrospective analysis 


\section{Availability of Data and Materials}

The datasets analyzed during current study are available from the corresponding author upon request

\section{References}

1. Winn HR. Low-grade glioma. In: Youmans and Winn Neurological Surgery. $7^{\text {th }}$ ed. New York: Elsevier; 2017. p. 4396.

2. National Organization for Rare Disorders, Astrocytoma; 2015. Available from: https://www.rarediseases.org/rare-diseases/ astrocytoma. [Last accessed on 2018 Aug 27].

3. American Brain Tumor Association, Glioblatoma and Malignan Astrocytoma; 2017.

4. Zhao W, Schachner M. Neureguline-1 enhances cell adhesion molecule L1 expression in human glioma cells and promotes their migration as a function of malignancy. J Neuropathol Exp Neurol. 2013;72(3):244-55. https://doi.org/10.1097/ nen.0b013e3182863dc5 PMid:23399902

5. Maiti AK, Ghosh K, Chatterjee U, Chakrobarti S, Chatterjee S. Epidermal growth factor receptor and proliferating cell nuclear antigen in astrocytoma. Neurol India. 2008;56(4):456-62. https:// doi.org/10.4103/0028-3886.44827

PMid:19127042

6. Forsyth PA, Swah EG, Scheithauer BW, O'Fallon JR, Layton DD, Katzmann JA. Supratentorial pilocytic astrocytoma. Cancer. 1993;72:1335-42.

7. Ritch PS, Carroll SL, Sontheimer H. Neuregulin-1 enhances survival of human astrocytic glioma cells. Glia. 2005;51(3):217-28. https://doi.org/10.1002/glia.2019 PMid:15812817

8. Pan B, Wang R, Huang Y, Garfiel D, Chen H. HGF and NRG1 protein expression are not poor prognostic markers in surgically resected lung adenocarcinoma. Onco Targets Ther. 2015;8:1185-91. https://doi.org/10.2147/ott.s78116

PMid:26045672
9. Perry A, Stafford SL, Scheithauer BW, Suman VJ, Lohse CM. Meningioma grading: An analysis of histologic parameters. Am J Surg Pathol. 1997;21(12):1455-65. https://doi. org/10.1097/00000478-199712000-00008 PMid:9414189

10. Douet V, Chang L, Pritchett A, Lee K, Keating B, Bartsch H, et al. Schizophrenia-risk variant rs6994992 in the neuregulin-1 gene on brain developmental trajectories in typically developing children. Transl Psychiatry. 2014;4(5):e392. https://doi. org/10.1038/tp.2014.41

PMid:24865593

11. Prevot V, Rio C, Cho GJ, Lomniczi A, Heger S, Neville CM, et al. Normal female sexual development requires neuregulinerbB receptor signaling in hypothalamic astrocytes. J Neurosci. 2003;23(1):230-9. https://doi.org/10.1523/ jneurosci.23-01-00230.2003

PMid: 12514220

12. Taylor SB, Markham JA, Taylor AR, Kanaskie BZ, Koenig JI. Sex-specific neuroendocrine and behavioral phenotypes in hypomorphic Type II neuregulin 1 rats. Behav Brain Res. 2011;224(2):223-32. https://doi.org/10.1016/j.bbr.2011.05.008 PMid:21620900

13. Ritch PA, Carroll SL, Sontheimer H. Neuregulin 1 Enhances Motility and Migration of Astrocytic Glioma Cell. Alabama: National Institutes of Health Public Access; 2003. https://doi. org/10.1074/jbc.m213074200

14. Wadugu B, Kuhn B. The role of neuregulin/ErbB2/Erbb4 signaling in the heart with special focus on effects on cardiomyocyte proliferation. Am J Physiol Heart Circ Physiol. 2012;302(11):H2139-47. https://doi.org/10.1152/ ajpheart.00063.2012 PMid:22427524

15. Liu Y, Ford BD, Mann MA, Fischbach GD. Neuregulin-1 increases the proliferation of neuronal progenitors from embryonic neural stem cells. Dev Biol. 2005;283(2):437-45. https://doi.org/10.1016/j.ydbio.2005.04.038 PMid:15949792

16. Anvari K, Seilanian Toussi M, Shahidsales S, Motlagh $F$, Reza Ehsaee M, Afshari F. Treatment outcomes and prognostic factors in adult astrocytoma: In North East of Iran. Iran J Cancer Prev. 2016;9(4):e4099. https://doi.org/10.17795/ijcp-4099 PMid:27822343 